\title{
Gambaran Pengetahuan, Sikap dan Perilaku Mayarakat di Wilayah Kerja Puskesmas Biru-Biru Terhadap Pencegahan Penyakit DBD
}

\section{The Description of Knowledge, Attitudes and Behavior of Communities in The Work Area of The Biru-Biru Health Center on the Prevention of DHF}

\section{Citra Cahyati Nst ${ }^{1}$, Delfriana Ayu A ${ }^{1}$, Pramilenia Rosdiana Putri ${ }^{1}$, Nurdinda Filza Mahzura ${ }^{1}$, Khalda Chofifah Muntaz ${ }^{1}$, Wahyu Opipa ${ }^{1}$, Indanazulfa ${ }^{1}$, Arfan Syahputra Pulungan' ${ }^{1}$, Nurhidayati ${ }^{1}$, Dewi Yunita Sembiring ${ }^{1}$, Zuliani Sasmitha ${ }^{1}$, Silfa Herawati Siregar ${ }^{1}$}

\author{
${ }^{1}$ Fakultas Kesehatan Masyarakat Universitas Islam Negeri Sumatera Utara, \\ Medan, Indonesia \\ *Korespondensi penulis: citra.cahyati@uinsu.ac.id
}

Penyerahan: 17-06-2020, Perbaikan: 24-07-2020, Diterima: 23-09-2020

\begin{abstract}
The Indonesian health program target in 2019 is $68 \%$ for Districts/Cities with IR DHF $<49$ per 100,000 population. However, what happened was that there were 23 provinces in 2019 that did not meet this target, including North Sumatra with IR 53.09. Deli Serdang Regency is the second region with the highest number of DHF cases in North Sumatra, there was 997 cases with IR DHF reaching 60.4\%. In efforts to prevent DHF, it is usually the obstacle in the community, based on public knowledge that affects attitudes and behavior in efforts to prevent DHF. The purpose of this study was to describe the knowledge, behavior, and behavior of the people in the work area of the Biru-Biru Health Center towards the prevention of DHF. This research was conducted in August 2020. Data collection was conducted using a questionnaire about knowledge, attitudes, and behavior with a total of 30 respondents who were selected using the accidental sampling method. The results showed that $55.33 \%$ of respondents had a good knowledge of DHF, $55.33 \%$ of respondents had a sufficiently anticipatory attitude towards preventing dengue disease, and in general $53.333 \%$ of respondents had sufficient behavior towards dengue, but prevention behavior against dengue only $6.67 \%$ good category.
\end{abstract}

Keywords: dengue hemorrhagic fever, knowledge, attitudes and behaviors

\begin{abstract}
ABSTRAK
Target program kesehatan Indonesia tahun 2019 sebesar 68\% Kabupaten/Kota dengan IR DBD <49 per 100.000 penduduk. Namun, kenyataan yang terjadi adalah terdapat 23 provinsi pada tahun 2019 yang tidak memenuhi target tersebut, termasuk Sumatera Utara dengan IR 53,09. Kabupaten Deli Serdang menjadi wilayah yang mempati urutan kedua dengan jumlah kasus DBD terbanyak di Sumatera Utara yakni 997 kasus dengan IR DBD mencapai $60,4 \%$. Dalam usaha pencegahan penyakit DBD biasanya yang menjadi hambatan di kalangan masyarakat ialah kurangnya pengetahuan masyarakat sehingga berpengaruh pada sikap dan perilaku dalam upaya pencegahan penyakit DBD. Tujuan penelitian ini untuk mengetahui gambaran pengetahuan, sikap, dan perilaku masyarakat di wilayah kerja Puskesmas Biru-Biru terhadap pencegahan penyakit DBD. Penelitian ini dilakukan pada Bulan Agustus 2020. Pengumpulan data dilakukan dengan
\end{abstract}


menggunakan kuesioner tentang pengetahuan, sikap, dan perilaku dengan jumlah responden sebanyak 30 orang yang dipilih dengan menggunakan metode accidental sampling. Hasil penelitian menunjukkan $55,33 \%$ responden memiliki pengetahuan yang baik mengenai tentang $\mathrm{DBD}, 55,33 \%$ responden memiliki sikap yang cukup antisipatif terhadap pencegahan penyakit DBD, dan pada umumnya $53.333 \%$ responden memiliki perilaku cukup terhadap penyakit DBD, namun perilaku pencegahan terhadap penyakit DBD dalam kategori yang baik hanya sebesar $6.67 \%$.

Kata Kunci : demam berdarah dangue, pengetahuan, sikap dan perilaku.

\section{PENDAHULUAN}

Kejadian demam berdarah telah meningkat secara drastis di seluruh dunia dalam beberapa dekade terakhir. Sebagian besar kasusnya tidak menunjukkan gejala sehingga terjadi penaikan jumlah kasus DBD dimana pada tahun 2010 berjumlah 2,2 juta kasus dan meningkat menjadi $>3,34$ juta pada tahun 2016. Peningkatan kasus tersebut terjadi hampir setiap tahun di lebih 100 negara endemis dengue termasuk Indonesia. Demam berdarah tersebar luas di seluruh daerah tropis, dengan variasi risiko lokal yang dipengaruhi oleh curah hujan, suhu, dan urbanisasi (Kolondam, B. P., Nelwan, J. E., \& Kandou, 2020). Penyakit Demam Berdarah Dengue (DBD) yang ditularkan melalui gigitan nyamuk dari genus Aedes, terutama Aedes aegypti atau Aedes albopictus yang dapat muncul sepanjang tahun dan dapat menyerang seluruh kelompok umur. Penyakit ini berkaitan dengan kondisi lingkungan, iklim, mobilisasi yang tinggi, kepadatan penduduk, perluasan perumahan dan perilaku masyarakat (Kemenkes RI, 2019a).

$$
\text { Jumlah kasus DBD di }
$$

Indonesia pada tahun 2018 berjumlah 65.602 kasus, dengan jumlah kematian sebanyak 467 orang. Jumlah tersebut menurun dari tahun sebelumnya, yaitu 68.407 kasus dan jumlah kematian sebanyak 493 orang (Kemenkes RI, 2018). Namun, pada tahun 2019 terjadi peningkatan ksus Kasus DBD yang sangat signifikan yakni 138.127 kasus (Kemenkes RI, 2019a). Penurunan case fatality rate (CFR) tahun sebelumnya tidak terlalu tinggi, yaitu $0,72 \%$ pada tahun 2017, menjadi $0,71 \%$ pada tahun 2018 dan 0,67\% pada tahun 2019 (Kemenkes RI, 2019b). Meskipun secara nasional, Angka Keparahan Penyakit (CFR) DBD menunjukkan sedikit penurunan, namun berdasarkan Profil Kesehatan Indonesia Tahun 2019 terjadi peningkatan IR DBD yang signifikan yaitu dari 24,75 per 100.000 penduduk di tahun 2018 menjadi 51.48 per 100.000 penduduk di tahun 2019 (Kemenkes RI, 2019a). Kasus penyakit DBD masih menjadi salah satu kasus penyakit yang tidak pernah berhenti dan menjadi program kesehatan prioritas di Indonesia. Target program kesehatan tahun 2019 yakni sebesar $68 \%$ kabupaten/kota dengan IR DBD $<49$ per 100.000 penduduk. Namun kenyataan yang terjadi adalah terdapat 23 provinsi pada tahun 2019 yang tidak memeuhi target IR DBD < 49 per 100.000 penduduk, termasuk Sumatera Utara dengan IR 53,09 (Kemenkes RI, 2019a).

Angka CFR dan IR di Provinsi Sumatera Utara sepanjang tahun 2013-2018 menunjukkan terjadinya penurunan dan peningkatan. Pada tahun 2014 CFR DBD sebesar $0,79 \%$ dan IR sebesar $51,9 \%$ dan mengalami penurunan pada tahun 
2015, yakni IR menjadi 41,4\% dan CFR sebesar 0,79\%. Selanjutnya, di tahun 2016, IR DBD mengalami peningkatan yang cukup pesat yakni $63,3 \%$ namun CFR terus menurun hingga 0,69\%. Pada tahun 2017 CFR dan IR DBD kembali menurun yakni IR sebesar 39,6\% dan CFR sebesar $0,51 \%$. Selanjutnya pada tahun 2018, IR DBD kembali mengalami peningkatan yakni menjadi $40,1 \%$ (Dinas Kesehatan Sumut, 2018).

Secara historis dalam kurun waktu beberapa tahun wilayah Sumatera Utara seluruhya pernah melaporkan adanya DBD di wilayahnya, namun pada tahun 2017 hanya satu (1) Kabupaten yang melaporkan tidak ada kasus DBD (nol kasus), yaitu Kabupaten Mandailing Natal. Bila dibandingkan dengan angka indikator keberhasilan program dalam menekan laju penyebaran $D B D$, yaitu IR DBD yang sebesar 39,6 /100.000 penduduk maka angka penyebaran kasus DBD Sumatera Utara ditemukan masih di atas indikator tersebut. Di sisi lain, CFR DBD tahun 2017 sebesar 0,51\% ditemukan relatif rendah dan sudah mampu mencapai target nasional,yaitu $<1 \%$. Hal ini mengindikasikan adanya peningkatan kesadaran masyarakat akan bahaya DBD, peningkatan sistem kewaspadaan dini DBD (Dinas Kesehatan Sumut, 2018).

$$
\text { Selanjutnya, adapun } 10
$$

Kabupaten / Kota di Provinsi Sumatera Utara yang memiliki kasus DBD tertinggi pada tahun 2018 antara lain Medan 1.490, Deli Serdang dengan jumlah kasus sebanyak 997 kasus, Langkat sebanyak 616 kasus, Simalungun sebanyak 445 kasus, Binjai 321 kasus, Tebing Tinggi sebayak 298 kasus, Pematang Siantar sebanyak 188 kasus, Serdang Bedagai 183 kasus, Gunung Sitoli 145 kasus dan
Dairi sebanyak 142 kasus (Dinas Kesehatan Sumut, 2018). Sebagai Kabupaten yang memiliki jumlah kasus paling banyak urutan kedua, Kabupaten Deli Serdang juga memiliki IR DBD yang sangat tinggi yaitu mencapai $60,4 \%$ pada tahun 2019 (Dinkes Kabupaten Deli Serdang, 2020).

Tingginya angka kejadian DBD maupun angka IR DBD mengindikasikan adanya masalah yang terjadi dalam proses optimalisasi penerapan upaya pencegahan DBD (Citrajaya, Hilda., 2016). Dalam usaha pencegahan penyakit DBD biasanya yang menjadi hambatan di kalangan masyarakat desa ialah kurangnya pengetahuan masyarakat sehingga berpengaruh pada sikap dan perilaku dalam upaya pencegahan penyakit DBD (Mangindaan, Mia A.V., Wulan Pingkan Julia Kaunang, 2018). Hal ini sejalan dengan penelitian Sitanggang (2019) yang melaporkan bahwa faktor-faktor risiko seperti tingkat pengetahuan, sikap dan perilaku masyarakat sekitar merupakan faktor yang berpengaruh terhadap prevalensi penyakit DBD karena semakin tinggi pengetahuan, sikap dan tindakan keluarga tentang pencegahan DBD akan membantu mengurangi angka kejadian DBD. Penelitian mengenai pengetahuan, sikap dan perilaku mayarakat terhadap Pencegahan Penyakit DBD telah dilakukan di salah satu desa dan kecamatan yang berada di wilayah Kabupaten Deli Serdang (Aritonang, Barita., Eka Magareta Sinaga., 2020; Sitanggang, 2019). Namun, sejauh penelusuran peneliti, penelitian yang sama secara spesifik di wilayah kerja Puskesmas Biru-Biru belum ditemukan.

Berdasarkan permasalahan di atas maka tujuan dari penelitian ini adalah untuk mengetahui tingkat 
pengetahuan, sikap dan perilaku masyarakat di Wilayah Kerja Puskesmas Biru-Biru, Kabupaten Deli Serdang, Provinsi Sumaterea Utara terhadap pencegahan Penyakit DBD. Dengan adanya penelitian ini, diharapkan dapat menjadi bahan pertimbangan dan intervensi terhadap upaya pencegahan penyakit DBD di wilayah Kerja Puskesmas Biru-Biru.

\section{METODE}

Penelitian ini merupakan penelitian deskstirptif kuantitatif dengan design studi crossectional. Disebut sebagai penelitian deskriptif karena penelitian ini bertujuan untuk menggambarkan pengetahuan, sikap dan perilaku masyarakat di Wilayah Kerja Puskesmas Biru-Biru, Kabupaten Deli Serdang, Provinsi Sumaterea Utara terhadap pencegahan Penyakit DBD. Penelitian ini dilakukan pada Bulan Agustus 2020 dengan menggunakan metode pemilihan sampel yakni accidental sampling dengan jumlah responden sebanyak 30 orang. Intrumen penelitian yang digunakan dalam penelitian ini berupa kuisioner yang telah diuji validitas dan reliabilitasnya. Analisis data yang digunakan dalam penelitian ini adalah analisis univariat yaitu statistik deskriptif untuk mendapatkan gambaran distribusi frekuensi dari pengetahuan, sikap dan perilaku terhadap pencegahan penyakit DBD.

Data yang diperoleh dari hasil penyebaran kuesioner disederhanakan dengan cara mengubah jawaban menjadi bentuk angka kemudian dimasukan kedalam komputer dalam bentuk skoring. Interpretasi data dilakukan dengan cara menggunakan rumus : $\mathrm{P}=\mathrm{X} / \mathrm{Y}$ $\mathrm{X} 100 \%$, dimana $\mathrm{P}=$ Persentase, $\mathrm{X}=$ jumlah skor yang diperoleh, $Y=$ Skor maksimum (Arikunto, 2006). Setelah diubah dalam bentuk persentase, kemudian hasil penelitian dikategorikan dengan 3 kategori, yakni : kategori baik $=76$ $\%-100 \%$, Cukup $=>56 \%-76 \%$, kurang baik $=\leq 56 \%$ (Arikunto, 2006). Setelah didapatkan kategori jawaban masing-masing individu, maka dihitung jumlah responden yang memiliki pengetahuan, sikap dan perilaku dalam masing-masing kategori dengan menggunakan Microsoft excel. Kemudian data disajikan dalam bentuk tabel dan diagram batang.

\section{HASIL dan PEMBAHASAN Karakteristik Responden}

Data Karakteristik responden yang di dapatkan selama proses pengambilan data meliputi : jenis kelamin, usia, pendidikan terakhir, status pernikahan, dan pekerjaan. Hasil rangkuman karakteristik responden dapat di lihat pada Tabel 1. 
Tabel. 1 Karakteristik Responden Penelitian

\begin{tabular}{lcc}
\hline Karakteristik responden & Jumlah $(\mathbf{n}) \mathbf{3 0}$ & Presentase (100\%) \\
\hline Jenis Kelamin & 9 & $30 \%$ \\
\hline Laki-laki & 21 & $70 \%$ \\
\hline Perempuan & 6 & $20 \%$ \\
\hline Usia & 10 & $33,33 \%$ \\
\hline $15-24$ & 6 & $20 \%$ \\
\hline $35-44$ & 8 & $26,67 \%$ \\
\hline $45-53$ & & $20 \%$ \\
\hline $54-67$ & 6 & $10 \%$ \\
\hline Pendidikan Terakhir & 3 & $66,67 \%$ \\
\hline SD & 20 & $3.33 \%$ \\
\hline SMP & 1 & $80 \%$ \\
\hline PMA & & $20 \%$ \\
\hline Status Pernikahan & 24 & \\
\hline Menikah & 6 & $40 \%$ \\
\hline Belum Menikah & & $60 \%$ \\
\hline Pekerjaan & 12 & \\
\hline Bekerja & 18 & \\
\hline Tidak Bekerja & & \\
\hline
\end{tabular}

Berdasarkan tabel di atas dapat diketahui bahwa mayoritas responden dalam penelitian ini berjenis kelamin perempuan yakni sebanyak 21 orang (70\%), sedangkan berjenis kelamin laki-laki sebanyak 9 orang (30\%) dengan mayoritas usia responden dalam ategori 35-44 tahun sebanyak 10 orang $(33,33 \%)$. Adapun pendidikan terkahir responden mayoritas pada kategori SMA yakni sebanyak 20 orang $(66,67 \%)$. Sebanyak 24 orang $(80 \%)$ sudah menikah dan mayoritas responden tidak bekerja yakni sebanyak 18 orang (60\%).

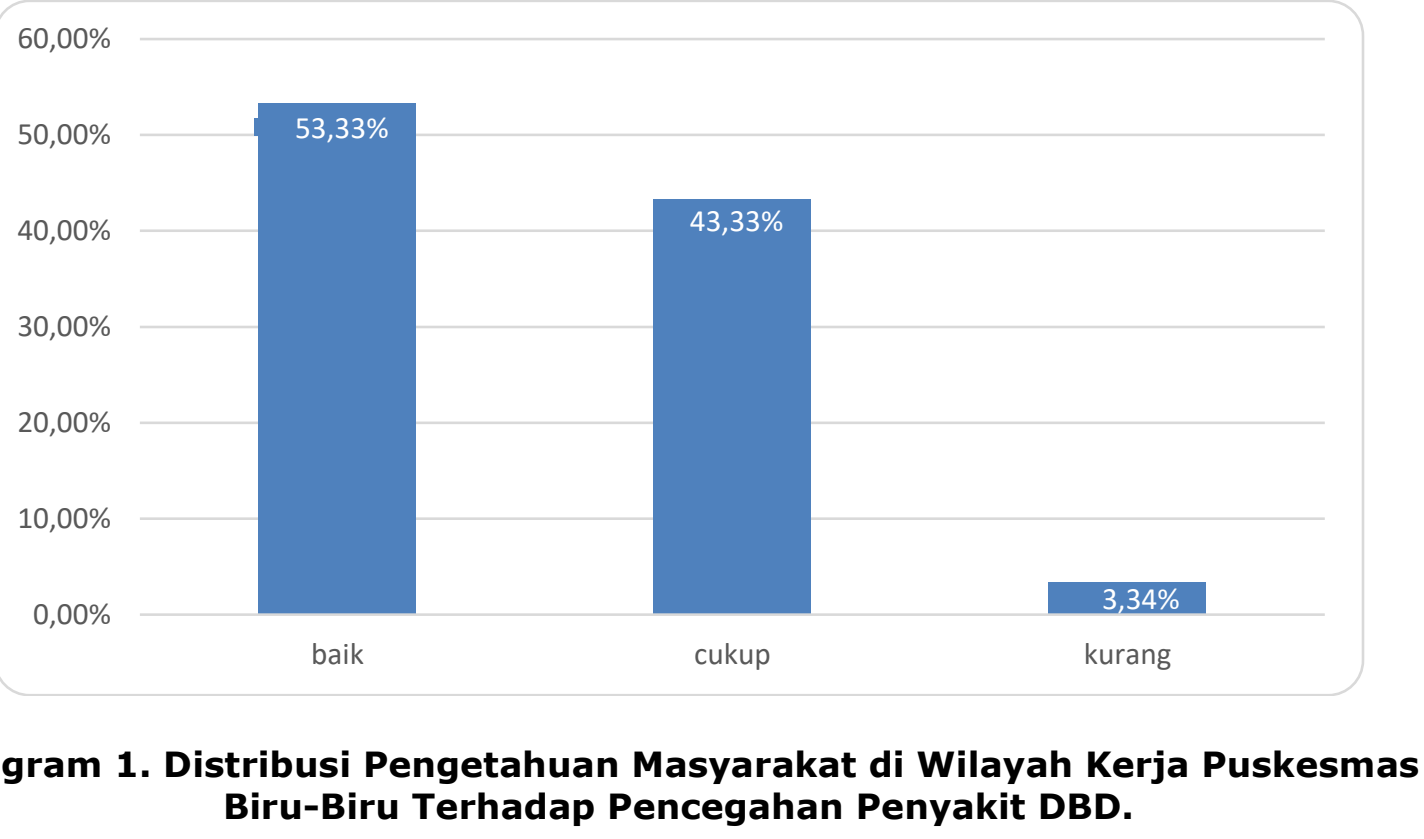


Berdasarkan diagram 1. dapat diketahui bahwa responden yang telah mengetahui atau memiliki pengetahuan terhadap pencegahan penyakit DBD yakni sebesar $53.33 \%$ menunjukkan dalam kategori baik, sebesar $43.333 \%$ dalam kategori cukup,namun adapula sebagian dari responden yang tidak mengetahui dan tidak memahami tentang pencegahan penyakit DBD sebesar 33.34\% menunjukkan dalam kategori kurang. Hal ini menunjukkan bahwa pada umumnya masyarakat di Wilayah Kerja Puskesmas Biru-Biru memiliki pengetahuan yang baik seputar tentang pencegahan penyakit DBD. $\mathrm{Hal}$ ini sejalan dengan penelitian Yosvara (2020) pada masyarkat Cikole, Jawa Barat yang menunjukkan bahwa sebesar $41.7 \%$ dari total responden memiliki pengetahuan yang baik terhadap pencegahan penyakit DBD. Penelitian Utami menegaskan bahwa pengetahuan memiliki peranan penting terhadap suatu perilaku. Pengetahuan seseorang akan sangat mempengaruhi perilaku orang tersebut dan mensugesti seseorang untuk melakukan suatu tindakan. Sejalan dengan penellitian Utami (2014), penelitian Azzahra (2015) juga melaporkan bahwa pengetahuan berperan penting dalam menentukan perilaku seseorang. Responden yang memahami bahaya DBD akan lebih berhati-hati dalam melakukan kegiatan sehari-hari karena mereka menyadari bahwa penyakit DBD dapat membahayakan diri mereka dan keluarga. Pengetahuan mengenai pencegahan penyakit DBD merupakan suatu hal yang sangat penting untuk diketahui masyarakat karena apabila masyarakat memiliki pengetahuan yang baik mengenai pencegahan penyakit DBD, maka akan semakin banyak masyarakat yang terhindar dari penyakit DBD (Shueai Al Awfi, M., AL Sharabi, B. A., Al Alimi, A., \& Abdo Abkar, 2019). Masih terdapatnya pengetahuan masyarakat yang kurang terhadap pencegahan penyakit DBD bisa karena kurangnya informasi yang didapatkan oleh masyarakat tentang pencegahan penyakit DBD (Lisastri Syahrias, 2018). Penelitian Dewi (2019) menegaskan sebuah cara yang dapat dilakukan untuk meningkatkan pengetahuan tentang penyakit DBD termasuk berhubungan dengan pencegahan penyakit DBD ialah bisa dengan melakukan komunikasi dengan teman sebaya yang ahli di bidang pencegahan penyakit DBD ataupun teman sebaya yang pernah mendapatkan penyukuhan tentang pencegahan penyakit DBD sehingga dapat memperoleh informasi yang lebih banyak dan meningkatkan pengetahuan mengenai pencegahan penyakit DBD. 
Gambaran Pengetahuan, Sikap dan Perilaku... (Citra Cahyati Nst, Delfriana Ayu A, Pramilenia Rosdiana Putri, Nurdinda Filza Mahzura, Khalda Chofifah Muntaz, Wahyu Opipa, Indanazulfa, Arfan Syahputra Pulungan, Nurhidayati, Dewi Yunita Sembiring, Zuliani Sasmitha, Silfa Herawati Siregar)

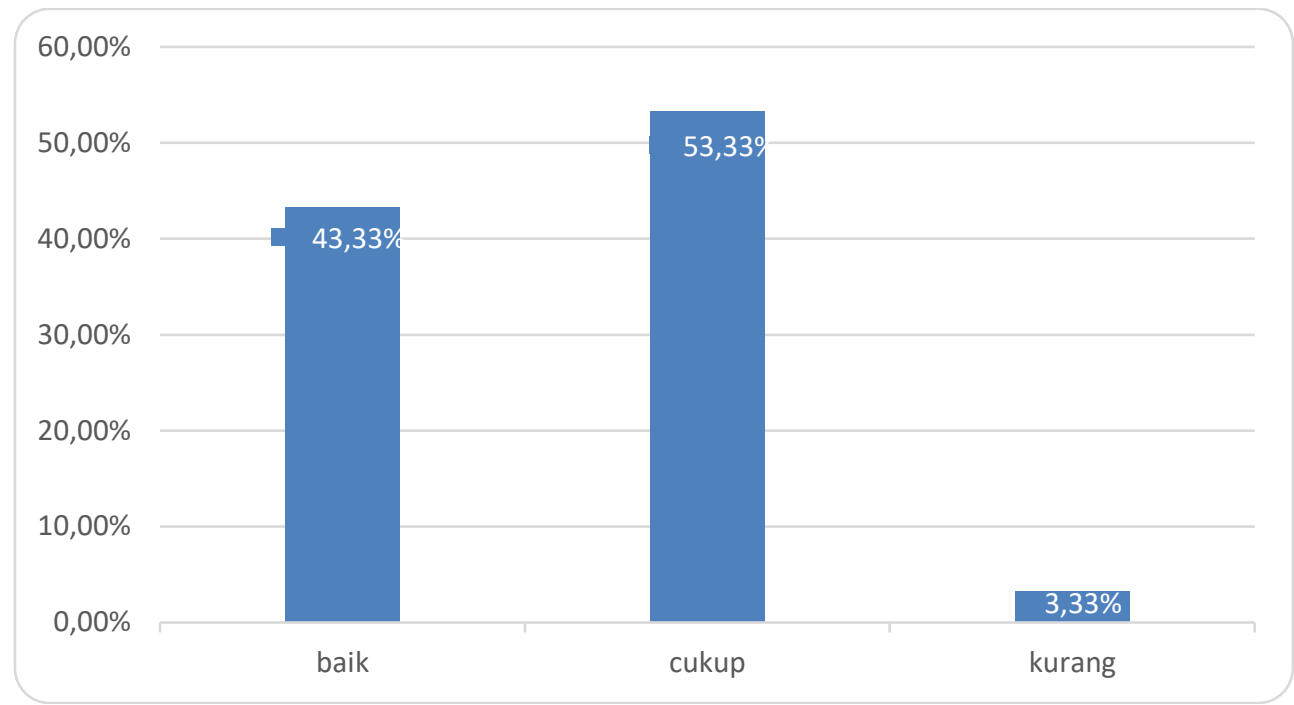

\section{Diagram 2. Distribusi Sikap Masyarakat di Wilayah Kerja Puskesmas Biru- Biru Terhadap Pencegahan Penyakit DBD}

Berdasarkan diagram 2. dapat diketahui bahwa tingkat sikap masyarakat di Wilayah Kerja Puskesmas Biru-Biru, Kecamatan Biru-Biru, Kabupaten Deli Serdang terhadap pencegahan penyakit DBD, yakni sebesar $53.33 \%$ dalam kategori cukup, $43.33 \%$ dalam kategori baik dan $3.33 \%$ dalam kategori kurang. Hal ini menunjukkan bahwa masyarakat pada umumnya memiliki sikap yang cukup antisipatif dalam pencegahan penyakit DBD.

Sikap merupakan faktor yang berperan dalam perilaku kesehatan. Semakin positif sikap atau pandangan seseorang terhadap sesuatu hal, maka semakin baik pula tindakan yang dilakukan dalam hal tersebut. Beberapa faktor yang mempengaruhi pembentukan sikap antara lain pengalaman pribadi, orang lain yang dianggap penting, dan pengaruh kebudayaan (Wawan A., 2010). Lontoh (2016) menyatakan bahwa Sikap mempunyai peranan penting di dalam perilaku kesehatan. Hal ini dapat ditunjukkan dari cara pandang individu dalam memberi nilai mengenai suatu hal yang sudah dilakukan. Semakin baik seseorang dalam menilai suatu hal. maka akan semakin baik juga tindakan yang akan dilakukan. Bila individu benarbenar bebas dari segala tekanan atau hambatan yang bisa mengganggu ekspresi sikapnya, maka dapat diharapkan bentuk perilaku yang tampak sebagai bentuk sebuah ekspresi yang sebenarnya. Timbulnya kemauan atau kehendak adalah sebagai bentuk lanjutan dari kesadaran dan pemahaman terhadap objek dalam hal ini adalah praktis PSN DBD. Kemauan atau kehendak merupakan kecenderungan untuk melakukan suatu tindakan (Ariani, 2016).

Tetapi sikap juga tidak selalu berujung dengan tindakan akan tetapi dapat dipelajari dan dibentuk berdasarkan pengalaman dan latihan sepanjang perkembangan seseorang maka sikap itu dapat berubah (Sari, 2020). Sikap akan berdampak pada perilaku setiap warga, dengan sikap yang baik diharapkan akan menimbulkan perilaku yang baik walaupun tidak selalu. Sikap merupakan reaksi atau respon yang masih tertutup dari seseorang terhadap suatu stimulus atau objek. 
Sikap merupakan predisposisi tindakan suatu perilaku. Sikap ini masih merupakan reaksi tertutup, bukan merupakan reaksi terbuka atau tingkah laku yang terbuka (Asrini, Akhmadi, \& Harjanto, 2007). Seseorang akan mengambil langkah yang berhubungan dengan kesehatan jika individu tersebut: "Merasa bahwa kondisi negatif kesehatan dapat dihindari, mempunyai ekspektasi positif bahwa jika dengan mengambil tindakan yang direkomendasikan, individu tersebut dapat menghindari kondisi kesehatan yang negatif, dan percaya bahwa individu tersebut dapat dengan sukses melakukan aksi kesehatan yang direkomendasikan" (Citrajaya, Hilda., 2016).

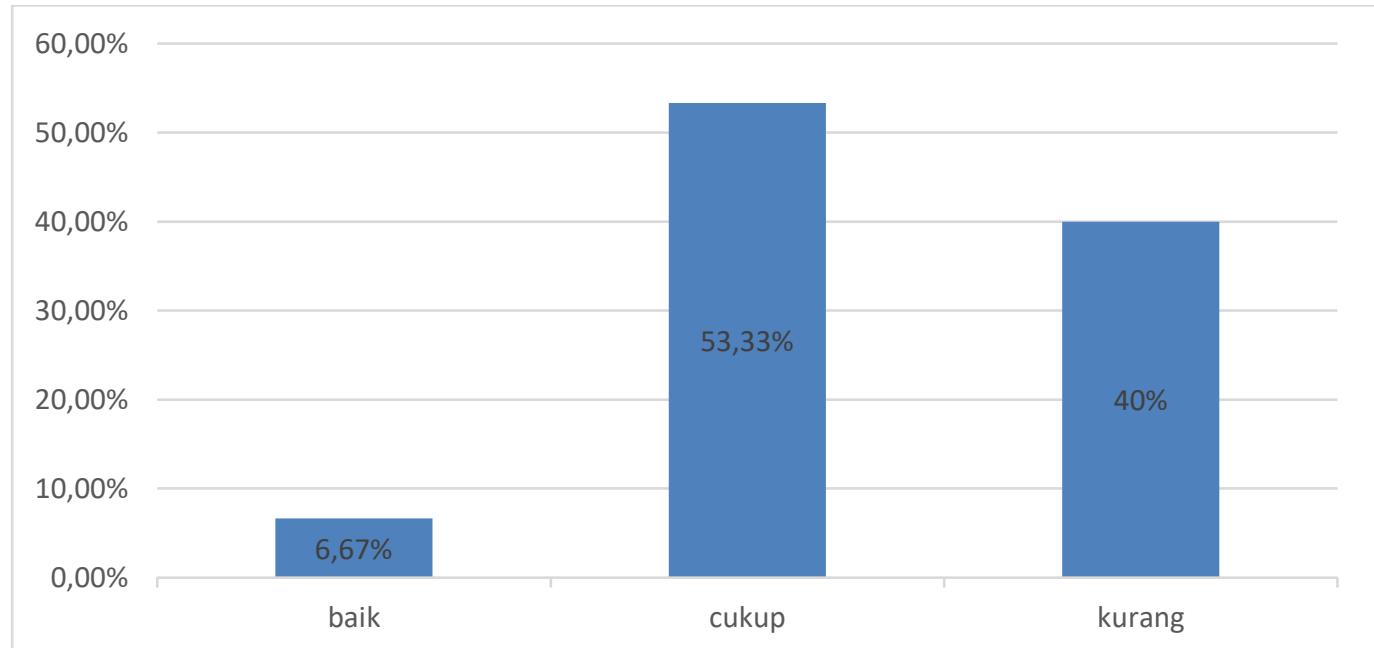

\section{Diagram 3. Distribusi Perilaku Masyarakat di Wilayah Kerja Puskesmas Biru- Biru Terhadap Pencegahan Penyakit DBD}

Berdasarkan diagram 3. dapat diketahui bahwa perilaku masyarakat di Wilayah Kerja Puskesmas BiruBiru, Kecamatan Biru-Biru, Kabupaten Deli Serdang terhadap pencegahan penyakit DBD, yakni sebesar $6.67 \%$ dalam kategori baik, kemudian sebesar $53.33 \%$ dalam kategori cukup dan $40 \%$ dalam kategori kurang. Dari hasil penelitian ini dapat dilihat bahwa sebagian besar masyarakat memiliki perilaku yang cukup terhadap pencegahan penyakit DBD akan tetapi tidak sedikit dari masyarakat yang menjadi responden dalam penelitian ini berada dalam kategori kurang dalam perilaku pencegahan DBD. Masyarakat juga belum sepenuhnya melaksanakan pencegahan DBD dengan baik.
Penelitian Harapan et al., (2018) menunjukkan bahwa faktor yang berperan dalam baiknya pemahaman responden terkait perilaku pencegahan DBD dipengaruhi oleh tingkat pendidikan yang tinggi, dimana dengan pendidikan yang tinggi maka pemahaman seseorang akan meningkat 14 kali lipat jika responden berlatar belakang tamatan perguruan tinggi. Sedangkan dapat kita lihat bahwa mayoritas masyarakat di Wilayah Kerja Puskesmas Biru-Biru, Kabupaten Deli Serdang, Provinsi Sumatera Utara yang menjadi responden dalam penelitian ini berlatar belakang pendidikan dalam kategori Sekolah Menengah Atas (SMA). Namun penelitian Harapan et al., (2018) berbanding terbalik 
dengan penelitian (Yosvara \& Atzmardina, 2020) yang menunjukkan hasil penelitiannya bahwa pendidikan yang rendah tidak membuat tingkat perilaku pencegahan menjadi rendah pula.

\section{SIMPULAN}

Meskipun mayoritas tingkat pengetahuan masyarakat di wilayah kerja Puskesmas Biru-Biru dalam kategori baik $(55,33 \%)$ terhadap pencegahan penyakit DBD dan mayoritas tingkat sikapnya dalam kategori cukup $(55,33 \%)$ dalam pencegahan penyakit DBD, namun tidak sedikit tingkat perilaku masyarakat di wilayah kerja Puskesmas Biru-Biru menunjukkan dalam kategori kurang (40\%) bahkan hanya minoritas masyarakat yang memiliki tingkat perilaku baik $(6,67 \%)$ dalam hal pencegahan penyakit DBD.

\section{SARAN}

Peneliti menyarankan adanya motivasi yang harus diberikan kepada masyarakat di wilayah kerja Puskesmas Biru-Biru agar masyarakat mau bertindak untuk melakukan pencegahan penyakit DBD karena sesungguhnya mayoritas masyarakat di wilayah kerja Puskesmas Biru-Biru telah memiliki pengetahuan yang baik dalam pencegahan penyakit DBD. Adapun motivasi tersebut dapat diperoleh dari peran aktif tenaga kesehatan Puskesmas Biru-Biru dan tokoh masyarakat di Wilayah Kerja Puskesmas Biru-Biru agar mengajak masyarakat bergotong royong untuk melakukan tindakan pencegahan penyakit DBD seperti melakukan pemberantasan sarang nyamuk Aedes aegypti dengan kegiatan 3M yakni Menguras atau membersihkan tempat penampungan air, Menutup rapat tempat-tempat penampungan air seperti drum, tong dan lain sebagainya, serta Mendaur ulang barang bekas yang memiliki potensi perkembangbiakan Aedes aegypti.

\section{DAFTAR PUSTAKA}

Ariani, A. . (2016). Demam Berdarah Dengue (DBD). Yogyakarta: Nuha Medika.

Arikunto, S. (2006). Prosedur Penelitian Suatu Pendekatan Praktik. Jakarta: PT. Rineka Cipta.

Aritonang, Barita., Eka Magareta Sinaga., \& N. F. A. (2020). Penyuluhan Tentang Malaria Di Desa Bintang Meriah Kecamatan Pancurbatu Kabupaten Deli Serdang. 1, 1-10.

Asrini, N., Akhmadi, A., \& Harjanto, D. (2007). Hubungan Antara Pengetahuan, Sikap Dan Perilaku Masyarakat Tentang Kegiatan Menguras, Menutup Dan Mengubur Dengan Angka Bebas Jentik. Jurnal IImu Keperawatan UGM, Vol. 2, pp. 89-92.

Azzahra, S. A. (2015). Gambaran Pengetahuan Sikap Dan

Tindakan Masyarakat Di Kelurahan Antang Kecamatan Manggala RW VI Tentang Penyalik Demam Berdarah Dengue (DBD) Kota Makassar Tahun 2015.

Citrajaya, Hilda., A. F. C. \& T. R. (2016). Gambaran Pengetahuan,Sikap dan Perilaku Masyarakat Dusun Payangan Terhadap Upaya Pencegahan Demam Berdarah Dengue. Retrieved from http://erepo.unud.ac.id/id/eprint /6258/1/8784bff69a0bea86d8da f089c551b686.pdf

Dewi, T. F., Wiyono, J., \& Ahmad, Z. S. (2019). Hubungan pengetahuan orang tua tentang 
penyakit DBD dengan perilaku pencegahan DBD di Kelurahan Tlogomas Kota Malang. Nursing News, 4(1), 348-358. Retrieved from

https://doi.org/10.1021/BC0498 $98 \mathrm{Y}$

Dinas Kesehatan Sumut. (2018). Profil Kesehatan Sumut 2017. Journal of Chemical Information and Modeling, 53(9), 16891699. Retrieved from https://doi.org/10.1017/СВ0978 1107415324.004

Dinkes Kabupaten Deli Serdang. (2020). Resume Profil Kesehatan Dinas Kesehatan Deli Serdang Tahun 2019.

Harapan, H., Rajamoorthy, Y., Anwar, S., Bustamam, A., Radiansyah, A., Angraini, P., ... Müller, R. (2018). Knowledge, attitude, and practice regarding dengue virus infection among inhabitants of Aceh, Indonesia: A cross-sectional study. BMC Infectious Diseases, 18(1), 116.

https://doi.org/10.1186/s12879018-3006-z

Kemenkes RI. (2018). Laporan Riskesdas 2018. In Kementerian Kesehatan Republlik Indonesia (Vol. 53). Retrieved from http://www.yankes.kemkes.go.i d/assets/downloads/PMK No. 57 Tahun 2013 tentang PTRM.pdf Kemenkes RI. (2019a). Profil Kesehatan Indonesia 2018 [Indonesia Health Profile 2018]. Retrieved from http://www.depkes.go.id/resour ces/download/pusdatin/profilkesehatan-indonesia/Data-danInformasi_Profil-KesehatanIndonesia-2018.pdf

Kemenkes RI. (2019b). Profil Kesehatan Indonesia 2018 [Indonesia Health Profile 2018]. Retrieved http://www.depkes.go.id/resour ces/download/pusdatin/profilkesehatan-indonesia/Data-danInformasi_Profil-KesehatanIndonesia-2018.pdf

Kolondam, B. P., Nelwan, J. E., \& Kandou, G. D. (2020). Gambaran Perilaku Masyarakat tentang Upaya Pencegahan Penyakit Demam Berdarah Dengue. Public Health and Community Medicine, 1(1), 1-5.

Lisastri Syahrias. (2018). Faktor Perilaku Pencegahan Demam Berdarah Dengue (DBD) di Kelurahan Mangsang, Kota Batam. Jurnal Dunia Kesmas, 7, 134-141.

Lontoh, R. Y., Rattu, A. J. M., \& Kaunang, W. P. J. (2016). Hubungan Antara Pengetahuan Dan Sikap Dengan Tindakan Pencegahan Demam Berdarah Dengue (Dbd) Di Kelurahan Malalayang 2 Lingkungan iii. Jurnal IImiah PHARMACON, 5(1), 382-389. Retrieved from https://ejournal.unsrat.ac.id/ind ex.php/pharmacon/article/view/ 11382

Mangindaan , Mia A.V., Wulan Pingkan Julia Kaunang, \& S. A. S. S. (2018). ). Hubungan Perilaku Pemberantasan Sarang Nyamuk dengan Kejadiam Demam Berdarah Dangue di Desa Watudambo Kecamatan Kauditan. Jurnal KESMAS, 7(5).

Sari, D. E. (2020). Pengetahuan, Sikap dan Pendidikan dengan Pencegahan Demam Berdarah Dengue Menggunakan Prinsip Menguras, Menutup dan Memanfaatkan Kembali. Jurnal Ilmiah STIKES Citra Delima Bangka Belitung, 3(2), 163-170. Shueai Al Awfi, M., AL Sharabi, B. A., Al Alimi, A., \& Abdo Abkar, M. (2019). Knowledge, Attitudes and Practices Regarding Dengue 
Gambaran Pengetahuan, Sikap dan Perilaku... (Citra Cahyati Nst, Delfriana Ayu A, Pramilenia Rosdiana Putri, Nurdinda Filza Mahzura, Khalda Chofifah Muntaz, Wahyu Opipa, Indanazulfa, Arfan Syahputra Pulungan,

Nurhidayati, Dewi Yunita Sembiring, Zuliani Sasmitha, Silfa Herawati Siregar)

Fever in a Cohort of Nursing Students. Advances in Medicine and Medical Research, 29(3), 19. Retrieved from https://doi.org/10.9734/jammr/ 2019/v29i330073

Sitanggang, S. (2019). Gambaran Pengetahuan, Sikap dan Tindakan Keluarga Trntang Pencegahan Demam Berdarah Dangue di Puskesmas Pancur Batu Kabupaten Deli Serdang Tahun 2019. Retrieved from http://repo.poltekkesmedan.ac.id/jspui/bitstream/123 456789/2093/1/JURNAL SOFIANA SITANGGANG.pdf
Utami.

(2014). Tindakan Pengetahuan dan Tindakan Masyarakat dengan Kejadian Demam Berdarah Dengue (DBD). Jurnal Berkala Epidemiologi, 3(2), 242-253.

Wawan A., D. M. (2010). Teori Dan Pengukuran Pengetahuan Sikap Dan Perilaku Manusia. Yogyakarta: Nuha Medika.

Yosvara, J., \& Atzmardina, Z. (2020). Gambaran pengetahuan dan sikap terhadap perilaku pencegahan penyakit demam berdarah pada masyarakat Cikole tahun 2019. 2(2), 294301. 